\title{
Observational Study of Chlorpromazine in Hospitalized Patients with Covid-19
}

Running title: Chlorpromazine in hospitalized patients with Covid-19

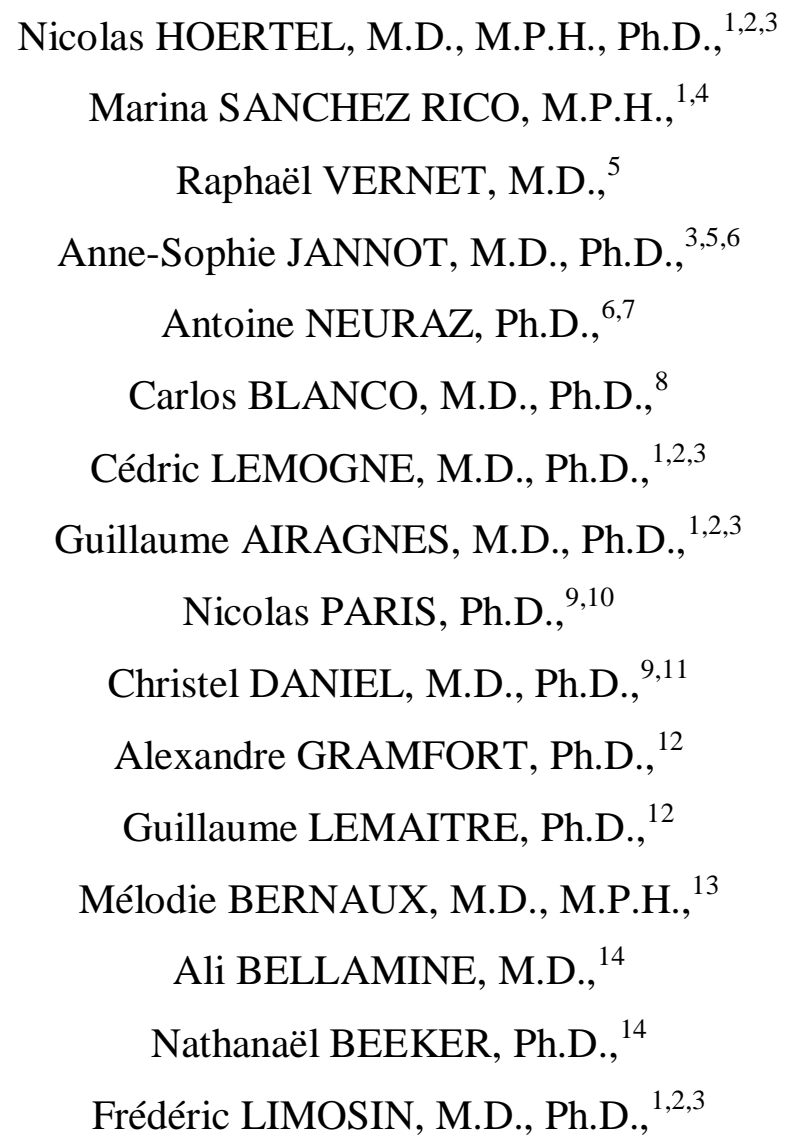

On behalf of AP-HP / Universities / INSERM Covid-19 research collaboration and APHP Covid CDR Initiative

1. AP-HP.Centre-Université de Paris, Hôpital Corentin-Celton, Département de Psychiatrie, Issy-les-Moulineaux, France.

2. Université de Paris, INSERM, Institut de Psychiatrie et Neurosciences de Paris, UMR_S1266, Paris, France.

3. Université de Paris, Faculté de Santé, UFR de Médecine, Paris, France. NOTE: This preprint reports new research that has not been certified by peer review and should not be used to guide clinical practice. 
medRxiv preprint doi: https://doi.org/10.1101/2020.07.15.20154310; this version posted July 16,2020 . The copyright holder for this preprint (which was not certified by peer review) is the author/funder, who has granted medRxiv a license to display the preprint in perpetuity. All rights reserved. No reuse allowed without permission.

4. Department of Psychobiology \& Behavioural Sciences Methods, Faculty of Psychology, Universidad Complutense de Madrid, Campus de Somosaguas, Pozuelo de Alarcon, Spain.

5. AP-HP.Centre-Université de Paris, Hôpital Européen Georges Pompidou, Medical Informatics, Biostatistics and Public Health Department, F-75015 Paris.

6. INSERM, UMR_S 1138, Cordeliers Research Center, Université de Paris.

7. Department of Medical Informatics, Necker-Enfants Malades Hospital, APHP.Centre-Université de Paris, 75015 Paris, France.

8. National Institute on Drug Abuse, Bethesda, MD, 20892, USA.

9. AP-HP, DSI-WIND, Paris, France.

10. LIMSI, CNRS, Université Paris-Sud, Université Paris-Saclay, F-91405, Orsay, France.

11. Sorbonne University, University Paris 13, Sorbonne Paris Cité, INSERM UMR_S 1142, F-75012 Paris, France

12. Université Paris-Saclay, Inria, CEA, Palaiseau, France.

13. Direction de la stratégie et de la transformation, AP-HP, Paris.

14. Unité de Recherche clinique, Hôpital Cochin, AP-HP.Centre-Université de Paris, Paris, France.

\section{Corresponding author}

Nicolas Hoertel, M.D., M.P.H., Ph.D.,

Corentin Celton Hospital, AP-HP.Centre, Paris University,

4 parvis Corentin Celton; 92130 Issy-les-Moulineaux, France

Phone: 0033 (0) 158004421

Fax: 0033 (0) 158004453

Email: nico.hoertel@yahoo.fr / nicolas.hoertel@aphp.fr 
medRxiv preprint doi: https://doi.org/10.1101/2020.07.15.20154310; this version posted July 16,2020 . The copyright holder for this preprint (which was not certified by peer review) is the author/funder, who has granted medRxiv a license to display the preprint in perpetuity.

All rights reserved. No reuse allowed without permission.

\begin{abstract}
On the grounds of its anti-inflammatory and potential antiviral effects, chlorpromazine has been suggested to be effective treatment for Covid-19. We examined the association between chlorpromazine use and respiratory failure among all hospitalized adults with Covid-19 at the 39 Greater Paris University hospitals since the beginning of the epidemic. Study baseline was defined as the date of hospital admission. The primary endpoint was a composite of intubation or death in a time-to-event analysis adjusting for numerous potential confounders. We used a multivariable Cox model with inverse probability weighting according to the propensity score. Of the 12,217 adult inpatients with a positive Covid-19 RT-PCR test included in the analyses, $57(0.47 \%)$ received chlorpromazine. Over a mean follow-up of 20.8 days, the primary endpoint occurred in 29 patients (50.9\%) exposed to chlorpromazine and 1,899 patients (15.6\%) who were not. In the main analysis, there was a positive significant association between chlorpromazine use and the outcome (HR, 1.67; 95\% CI, 1.09 to 2.56, $\mathrm{p}=0.019$ ), while a Cox regression in a matched analytic sample yielded non-significant association $(1.38 ; 95 \% \mathrm{CI}, 0.91$ to $2.09, \mathrm{p}=0.123)$. These findings suggest that chlorpromazine is unlikely to have a clinical efficacy for Covid-19.
\end{abstract}

Key words: Covid-19; SARS-CoV-2; chlorpromazine; treatment; efficacy; death; intubation. 
medRxiv preprint doi: https://doi.org/10.1101/2020.07.15.20154310; this version posted July 16,2020 . The copyright holder for this preprint (which was not certified by peer review) is the author/funder, who has granted medRxiv a license to display the preprint in perpetuity.

\section{Introduction}

Global spread of the novel coronavirus SARS-CoV-2, the causative agent of coronavirus disease 2019 (Covid-19), has created an unprecedented infectious disease crisis worldwide. In the absence of a vaccine or antiviral medications with proven clinical efficacy ${ }^{1,2}$, the search for an effective treatment for patients with Covid-19 among all available medications is urgently needed ${ }^{2,3}$.

Chlorpromazine, a dimethylamine derivative of phenothiazine used in the treatment of acute and chronic psychoses ${ }^{4}$, has been suggested as potential effective treatment for Covid19 on the grounds of its antiviral and anti-inflammatory effects ${ }^{5}$. Specifically, several in-vitro studies ${ }^{6-8}$ showed that chlorpromazine reduces viral replication of coronavirus-229E, MERSCoV et SARS-CoV-1, possibly through the inhibition of clathrin-mediated endocytosis ${ }^{9,10}$. Furthermore, several mouse models of sepsis ${ }^{11-14}$ suggest that this medication is associated with a decrease in pro-inflammatory cytokines, including IL-2, IL4, IFN alpha, TNF, and GM-CSF, and an increase of the anti-inflammatory cytokine IL-10. Short-term use of chlorpromazine is generally well tolerated ${ }^{5,15}$, although side effects can occur, including QT interval prolongation, extrapyramidal symptoms, dry mouth, dizziness, urine retention, blurred vision, constipation, and hyperprolactinemia ${ }^{5,15}$.

To our knowledge, no study has examined to date the potential efficacy of chlorpromazine for Covid-19 in clinical populations. Observational studies of patients with Covid-19 taking medications for other indications can help determine their efficacy for Covid-19 and decide which medications should be prioritized for randomized clinical trials, and minimize the risk for patients of being exposed to potentially harmful and ineffective treatments.

To this end, we took advantage of the continuously updated Assistance Publique-Hôpitaux de Paris (AP-HP) Health Data Warehouse, which includes all inpatient visits for Covid-19 to one of the 39 Greater Paris University hospitals since the beginning of the epidemic. 
medRxiv preprint doi: https://doi.org/10.1101/2020.07.15.20154310; this version posted July 16,2020 . The copyright holder for this preprint (which was not certified by peer review) is the author/funder, who has granted medRxiv a license to display the preprint in perpetuity.

All rights reserved. No reuse allowed without permission.

In this report, we examined the association between chlorpromazine use and respiratory failure among adult patients with Covid-19 who have been hospitalized in these medical centers. We hypothesized that chlorpromazine use would be associated with a lower risk of a composite endpoint of intubation or death in a time-to-event analyses that were adjusted for major predictors of respiratory failure and weighted according to propensity scores assessing the probability of chlorpromazine use.

\section{Methods}

\subsection{Setting}

We conducted this study at AP-HP, which comprises 39 hospitals, 23 of which are acute, 20 adult and 3 pediatric hospitals. We included all adults aged 18 years or over who have been admitted to the hospital with Covid-19 from the beginning of the epidemic in France, i.e. January $24^{\text {th }}$, until May $20^{\text {th }}$. In all patients, Covid-19 infection was ascertained by a positive reverse-transcriptase-polymerase-chain-reaction (RT-PCR) test from analysis of nasopharyngeal or oropharyngeal swab specimens. This observational non-interventional retrospective study using routinely collected data received approval from the Institutional Review Board of the AP-HP clinical data warehouse (decision CSE-20-20_COVID19, IRB00011591). AP-HP clinical Data Warehouse initiative ensures patients' information and consent regarding the different approved studies through a transparency portal in accordance with European Regulation on data protection and authorization $\mathrm{n}^{\circ} 1980120$ from National Commission for Information Technology and Civil Liberties (CNIL). Participants who did not consent to participate in the study were excluded. All procedures related to this work adhered to the ethical standards of the relevant national and institutional committees on human experimentation and with the Helsinki Declaration of 1975, as revised in 2008. 
medRxiv preprint doi: https://doi.org/10.1101/2020.07.15.20154310; this version posted July 16,2020 . The copyright holder for this preprint (which was not certified by peer review) is the author/funder, who has granted medRxiv a license to display the preprint in perpetuity.

\subsection{Data sources}

We used data from the AP-HP Health Data Warehouse ('Entrepôt de Données de Santé (EDS)'). This warehouse contains all the clinical data available on all inpatient visits for Covid-19 to any of the 39 AP-HP Greater Paris University hospitals. The data obtained included patients' demographic characteristics, RT-PCR test results, medication administration data, past and current medication lists, past and current diagnoses, discharge disposition, ventilator use data, and death certificates.

\subsection{Variables assessed}

We obtained the following data for each patient at the time of the hospitalization: sex; age; obesity (defined as having a body-mass index higher than $30 \mathrm{~kg} / \mathrm{m}^{2}$ or an International Statistical Classification of Diseases and Related Health Problems (ICD-10) diagnosis code for obesity (E66.0, E66.1, E66.2, E66.8, E66.9); self-reported smoking status; any medical condition associated with increased risk of severe SARS-CoV-2 infection ${ }^{16-21}$, which were coded by practitioners based on ICD-10, including diabetes mellitus (E11), diseases of the circulatory system (I00-I99), diseases of the respiratory system (J00-J99), neoplasms (C00D49), and diseases of the blood and blood-forming organs and certain disorders involving the immune mechanism (D5-D8); and any medication prescribed according to compassionate use or as part of clinical trials (e.g., hydroxychloroquine, azithromycin, remdesivir, tocilizumab, or sarilumab). To take into account possible confounding by indication bias for chlorpromazine, we recorded whether patients had any current psychiatric disorder, including delirium (F00-F99 and R41.0), and whether they were prescribed any antipsychotic medication other than chlorpromazine, any benzodiazepine or Z-drug, or any other psychotropic medication (i.e., antidepressants or mood stabilizers). 
medRxiv preprint doi: https://doi.org/10.1101/2020.07.15.20154310; this version posted July 16,2020 . The copyright holder for this preprint (which was not certified by peer review) is the author/funder, who has granted medRxiv a license to display the preprint in perpetuity.

All rights reserved. No reuse allowed without permission.

All medical notes and prescriptions are computerized in Greater Paris University hospitals. Medications and their mode of administration (i.e., dosage, frequency, date, condition of intake) were identified from medication administration data or scanned handwritten medical prescriptions, through two deep learning models based on BERT contextual embeddings ${ }^{22}$, one for the medications and another for their mode of administration. The model was trained on the APmed corpus ${ }^{23}$, a previously annotated dataset for this task. Extracted medications names were then normalized to the Anatomical Therapeutic Chemical (ATC) terminology using approximate string matching.

\subsection{Exposure to chlorpromazine}

Study baseline was defined as the date of hospital admission. Patients were considered to have been exposed to chlorpromazine if they were under this medication at admission, ascertained by an ongoing medical prescription dated of less than 3 months before hospital admission, or if they received it during the follow-up period before the end of the hospitalization or intubation or death.

\subsection{Endpoints}

The primary endpoint was the time from study baseline to intubation or death. For patients who died after intubation, the primary endpoint was defined as the time of intubation. Patients without an end-point event had their data censored on May $20^{\text {th }}, 2020$.

\subsection{Statistical analysis}

We calculated frequencies and means ( \pm standard deviations $(\mathrm{SD})$ ) of each variable described above in patients exposed and not exposed to chlorpromazine and compared them using chi-square tests or Welch's t-tests. 
medRxiv preprint doi: https://doi.org/10.1101/2020.07.15.20154310; this version posted July 16,2020 . The copyright holder for this preprint (which was not certified by peer review) is the author/funder, who has granted medRxiv a license to display the preprint in perpetuity.

All rights reserved. No reuse allowed without permission.

To examine the association of chlorpromazine use with the primary composite endpoint (i.e., intubation or death), we performed Cox proportional-hazards regression models. Weighted Cox regression models were used when the proportional hazards assumption was not met. To help account for the nonrandomized prescription of chlorpromazine and reduce the effects of confounding, the primary analysis used propensity score analysis with inverse probability weighting ${ }^{24,25}$. The individual propensities for chlorpromazine prescription were estimated by a multivariable logistic regression model that included sex, age, obesity, smoking status, any medical condition, any medication prescribed according to compassionate use or as part of a clinical trial, any current psychiatric disorder (including delirium), any antipsychotic medication other than chlorpromazine, any benzodiazepine or Z-drug, and any other psychotropic medication. In the inverse-probabilityweighted analysis, the predicted probabilities from the propensity-score model were used to calculate the stabilized inverse-probability-weighting weight ${ }^{24}$. Association between chlorpromazine use and the primary endpoint was then estimated using a multivariable Cox regression model using the inverse-probability-weighting weights. Kaplan-Meier curves were performed using the inverse-probability-weighting weights ${ }^{26}$, and their pointwise $95 \%$ confidence intervals were estimated using the nonparametric bootstrap method ${ }^{27}$.

We conducted sensitivity analyses, including a multivariable Cox regression model comprising as covariates the same variables as the inverse-probability-weighted analysis, and a univariate Cox regression model in a matched analytic sample. For this latter analysis, we selected five controls for each exposed case, based on the same variables used for both the inverse-probability-weighted analysis and the multivariable Cox regression. To reduce the effects of confounding, optimal matching was used in order to obtain the smallest average absolute distance across all these characteristics between each exposed patient and its five corresponding non-exposed matched controls. 
medRxiv preprint doi: https://doi.org/10.1101/2020.07.15.20154310; this version posted July 16,2020 . The copyright holder for this preprint (which was not certified by peer review) is the author/funder, who has granted medRxiv a license to display the preprint in perpetuity.

All rights reserved. No reuse allowed without permission.

Finally, within the group of patients exposed to chlorpromazine, we tested the association of daily dosage and duration of exposure (dichotomized into 'prescription that began during the hospitalization' and 'prescription that started before hospitalization') with the primary endpoint.

For all significant associations, we performed residual analyses to assess the fit of the data, check assumptions, including the proportional hazards assumption, and examined the potential influence of outliers. To improve the quality of result reporting, we followed the recommendations of The Strengthening the Reporting of Observational Studies in Epidemiology (STROBE) Initiative. ${ }^{28}$ Statistical significance was fixed a priori at $\mathrm{p}<0.05$. All analyses were conducted between June $5^{\text {th }}$ and June $15^{\text {th }}$ in R software version 2.4.3.

\section{Results}

\subsection{Characteristics of the cohort}

Of the 16,170 hospitalized adult patients with a positive Covid-19 RT-PCR test, a total of 3,953 patients $(24.4 \%)$ were excluded because of missing data. Of the remaining 12,217 adult inpatients, 57 patients $(0.47 \%)$ were exposed to chlorpromazine, at a mean dosage of $79.5 \mathrm{mg}$ per day $(\mathrm{SD}=71.6$; median=50 $\mathrm{mg}$; range: $6.0 \mathrm{mg}$ to $300.0 \mathrm{mg}$ ), and this exposure started after hospital admission in most of them $(84.2 \%, \mathrm{n}=48)$ (Figure 1).

Over a mean follow-up of 17.8 days $(\mathrm{SD}=24.0$; median=5 days; range: 1 day to 117 days), 1,624 patients (13.3\%) had a primary end-point event prior to the completion of data collection on May $20^{\text {th }}$. In patients exposed to chlorpromazine, the mean follow-up was 21.1 days $(\mathrm{SD}=21.7$; median=12 days; range: 1 day to 83 days), while it was of 18.7 days ( $\mathrm{SD}=24.3$; median=6 days; range: 1 day to 117 days) for those who were not exposed to chlorpromazine. 
medRxiv preprint doi: https://doi.org/10.1101/2020.07.15.20154310; this version posted July 16,2020 . The copyright holder for this preprint (which was not certified by peer review) is the author/funder, who has granted medRxiv a license to display the preprint in perpetuity.

All rights reserved. No reuse allowed without permission.

The distribution of the patients' characteristics by chlorpromazine exposure status is shown in Table 1. In the full sample, chlorpromazine exposure significantly differed according to presence of obesity, any medical condition, any current psychiatric disorder, any psychotropic medication other than chlorpromazine, any benzodiazepine or Z-drug, and any other psychotropic medication, and the direction of associations indicated greater medical severity of people receiving chlorpromazine than those who did not. After applying the propensity score weights, these differences were substantially reduced and remained significant only for any current psychiatric disorder, any benzodiazepine or Z-drug, and any other psychotropic medication (Table 1).

In the matched analytic sample comprising 342 patients (i.e., 57 patients exposed to chlorpromazine and 285 patients from the matched group), there were no significant differences in any characteristic according to chlorpromazine exposure (Table 1).

\subsection{Study endpoint}

Respiratory failure occurred in 23 patients $(40.4 \%)$ who received chlorpromazine and 1,619 patients $(13.3 \%)$ who did not (Table 2). There was a significant positive association between chlorpromazine use and the composite primary endpoint in both the crude, unadjusted analysis (hazard ratio (HR), 2.85; $95 \% \mathrm{CI}, 1.97$ to $4.12, \mathrm{p}<0.001$ ) and the primary multivariable analysis with inverse probability weighting (HR, 1.67; 95\% CI, 1.09 to 2.56, p=0.019) (Figure 2; Table 2). In sensitivity analyses, the multivariable Cox regression model in the full sample yielded a similar result (hazard ratio (HR), 1.96; 95\% CI, 1.34 to 2.86, $\mathrm{p}<0.001)$. However, this association was not significant in the univariate Cox regression model in the matched analytic sample (hazard ratio (HR), 1.38; 95\% CI, 0.91 to 2.09, $\mathrm{p}=0.123$ ), for which differences across all characteristics between exposed and non-exposed cases were not significant (Figure 2; Table 2). 
medRxiv preprint doi: https://doi.org/10.1101/2020.07.15.20154310; this version posted July 16,2020 . The copyright holder for this preprint (which was not certified by peer review) is the author/funder, who has granted medRxiv a license to display the preprint in perpetuity.

All rights reserved. No reuse allowed without permission.

When restricting the analyses to the 48 patients who received chlorpromazine only during the hospitalization, the association between chlorpromazine use and the primary endpoint was significant in the propensity score weighted analysis (HR, 2.00; 95\% CI, 1.31 to 3.02, $\mathrm{p}=0.001)$, but not in the matched analytic sample analysis $(\mathrm{HR}, 1.53 ; 95 \% \mathrm{CI}, 1.00$ to 2.37 , $\mathrm{p}=0.051)$ (Supplemental eFigure 1). When restricting the analyses to the 9 patients exposed to chlorpromazine in the 3 months prior to the hospitalization only, this association was not significant in the propensity score weighted analysis (HR, $0.86 ; 95 \% \mathrm{CI}, 0.25$ to 2.90 , $\mathrm{p}=0.808)$ or in the matched analytic sample analysis (HR, $0.74 ; 95 \% \mathrm{CI}, 0.23$ to 2.32, $\mathrm{p}=0.602)($ Supplemental eFigure 2)

A post-hoc analysis indicated that in the full sample, we had $80 \%$ power to detect hazard ratios for chlorpromazine treatment of at least $2.38 / 0.42$ for the primary endpoint.

Finally, there were no significant associations of daily chlorpromazine dosage or duration of exposure with the primary endpoint [HR $(95 \% \mathrm{CI}), 0.99(0.98-1.01), \mathrm{p}=0.191$; and HR (95\% CI), $2.73(0.64-11.75), \mathrm{p}=0.177$, respectively].

\section{Discussion}

In this observational multicenter study involving a large number of inpatients with Covid-19, exposure to chlorpromazine was not significantly associated with risk of intubation or death. Although these findings should be interpreted with caution due to the observational design, the wide confidence intervals for estimates, and the fact that this is, to our knowledge, the first study examining the association of chlorpromazine use with respiratory failure in a clinical population of patients with Covid-19, our results suggest that chlorpromazine is unlikely to have a clinical efficacy for Covid-19.

In the analyses, we tried to minimize the effects of confounding in several different ways. First, we used a multivariable regression model with inverse probability weighting to 
medRxiv preprint doi: https://doi.org/10.1101/2020.07.15.20154310; this version posted July 16,2020 . The copyright holder for this preprint (which was not certified by peer review) is the author/funder, who has granted medRxiv a license to display the preprint in perpetuity.

All rights reserved. No reuse allowed without permission.

minimize the effects of confounding by indication ${ }^{24,25}$. We also performed sensitivity analyses, including a multivariable Cox regression model and a univariate Cox regression model in a matched analytic sample, which respectively showed a significant positive association between use of chlorpromazine and the primary endpoint and a non-significant association, giving strength to the conclusion that chlorpromazine in unlikely to reduce risk of intubation or death.

Second, although some amount of unmeasured confounding may remain, our analyses adjusted for numerous potential confounders, including sex, age, obesity, smoking status, any medical condition, any medication prescribed according to compassionate use or as part of a clinical trial, any current psychiatric disorder (including delirium), any prescribed antipsychotic medication other than chlorpromazine, any benzodiazepine or Z-drug, and any other psychotropic medication. Finally, the lack of significant associations of daily chlorpromazine dosage or duration of exposure with the endpoint of intubation or death further supports our conclusion.

Additional limitations of our study include missing data for some variables and potential for inaccuracies in the electronic health records, such as the possible lack of documentation of illnesses or medications, or the misidentification of treatment mode of administration (e.g., dosage, frequency), especially for hand-written medical prescriptions. However, results remained unchanged after using multiple imputation to account for missing data (available on request). Furthermore, patients under chlorpromazine were prescribed a relatively low dosage, i.e., $75 \mathrm{mg}$ per day $(\mathrm{SD}=4.3)$, and its antiviral properties might be observable at higher dosages. However, we did not find a significant association between dosage and the primary endpoint. In addition, despite the multicenter design, our results may not be generalizable to other settings or regions. Finally, it is possible that chlorpromazine prescription was motivated mainly by the presence of agitation, which might be a marker of 
medRxiv preprint doi: https://doi.org/10.1101/2020.07.15.20154310; this version posted July 16,2020 . The copyright holder for this preprint (which was not certified by peer review) is the author/funder, who has granted medRxiv a license to display the preprint in perpetuity.

All rights reserved. No reuse allowed without permission.

severity of Covid-19. However, the analyses adjusted for current psychiatric disorders, including delirium, and non-psychiatric medical conditions.

In this observational study involving patients with Covid-19 who had been admitted to the hospital, chlorpromazine use was not associated with a lower risk of intubation or death. The results suggest that chlorpromazine is unlikely to have a clinical efficacy for Covid-19.

\section{References}

1 Anderson, R. M., Heesterbeek, H., Klinkenberg, D. \& Hollingsworth, T. D. How will country-based mitigation measures influence the course of the COVID-19 epidemic? Lancet 395, 931-934, doi:10.1016/S0140-6736(20)30567-5 (2020).

2 Gordon, D. E. et al. A SARS-CoV-2 protein interaction map reveals targets for drug repurposing. Nature, 1-13 (2020).

3 Chevance, A. et al. Ensuring mental health care during the SARS-CoV-2 epidemic in France: a narrative review. L'encephale (2020).

4 Delay, J., Deniker, P. and Harl, J. M. Utilisation en therapeutique psychiatrique d'une phenothiazine d'action centrale elective. Annales medico-psychologiques vol. 110, 112-7 (1952).

5 Plaze, M. et al. Repurposing of chlorpromazine in COVID-19 treatment: the reCoVery study. L'Encephale, S0013-7006 (2020).

6 de Wilde, A. H. et al. Screening of an FDA-approved compound library identifies four small-molecule inhibitors of Middle East respiratory syndrome coronavirus replication in cell culture. Antimicrobial agents and chemotherapy 58, 4875-4884 (2014).

7 Dyall, J. et al. Repurposing of clinically developed drugs for treatment of Middle East respiratory syndrome coronavirus infection. Antimicrobial agents and chemotherapy 58, 4885-4893 (2014).

8 Cong, Y. et al. MERS-CoV pathogenesis and antiviral efficacy of licensed drugs in human monocyte-derived antigen-presenting cells. PloS one 13 (2018).

9 Daniel, J. A. et al. Phenothiazine - derived antipsychotic drugs inhibit dynamin and clathrin - mediated endocytosis. Traffic 16, 635-654 (2015).

10 Wang, L.-H., Rothberg, K. G. \& Anderson, R. Mis-assembly of clathrin lattices on endosomes reveals a regulatory switch for coated pit formation. The Journal of cell biology 123, 1107-1117 (1993).

11 Bertini, R., Garattini, S., Delgado, R. \& Ghezzi, P. Pharmacological activities of chlorpromazine involved in the inhibition of tumour necrosis factor production in vivo in mice. Immunology 79, 217 (1993).

12 Gadina, M. et al. Protective effect of chlorpromazine on endotoxin toxicity and TNF production in glucocorticoid-sensitive and glucocorticoid-resistant models of endotoxic shock. The Journal of experimental medicine 173, 1305-1310 (1991).

13 Mengozzi, M. et al. Chlorpromazine specifically inhibits peripheral and brain TNF production, and up-regulates IL-10 production, in mice. Immunology 82, 207 (1994).

14 Tarazona, R. et al. Chlorpromazine amplifies macrophage-dependent IL-10 production in vivo. The Journal of Immunology 154, 861-870 (1995). 
medRxiv preprint doi: https://doi.org/10.1101/2020.07.15.20154310; this version posted July 16,2020 . The copyright holder for this preprint (which was not certified by peer review) is the author/funder, who has granted medRxiv a license to display the preprint in perpetuity.

All rights reserved. No reuse allowed without permission.

15 Mann, S. K. \& Marwaha, R. Chlorpromazine. StatPearls [Internet] (StatPearls Publishing, 2019).

16 Zhou, F. et al. Clinical course and risk factors for mortality of adult inpatients with COVID-19 in Wuhan, China: a retrospective cohort study. The Lancet (2020).

17 Ruan, Q., Yang, K., Wang, W., Jiang, L. \& Song, J. Clinical predictors of mortality due to COVID-19 based on an analysis of data of 150 patients from Wuhan, China. Intensive care medicine 46, 846-848 (2020).

18 Salje, H. et al. Estimating the burden of SARS-CoV-2 in France. Science (2020).

19 Hur, K. et al. Factors Associated With Intubation and Prolonged Intubation in Hospitalized Patients With COVID-19. Otolaryngology--Head and Neck Surgery (2020).

20 Vardavas, C. I. \& Nikitara, K. COVID-19 and smoking: A systematic review of the evidence. Tobacco Induced Diseases 18 (2020).

21 Ryan, D. H., Ravussin, E. \& Heymsfield, S. COVID 19 and the Patient with ObesityThe Editors Speak Out. Obesity (Silver Spring, Md.) (2020).

22 Devlin, J., Chang, M.-W., Lee, K. \& Toutanova, K. Bert: Pre-training of deep bidirectional transformers for language understanding. arXiv preprint arXiv:1810.04805 (2018).

23 Jouffroy, J. et al. MedExt: combining expert knowledge and deep learning for medication extraction from French clinical texts (2020).

24 Robins, J. M., Hernan, M. A. \& Brumback, B. Marginal structural models and causal inference in epidemiology. Epidemiology 11, 550-560 (2000).

25 Geleris, J. et al. Observational study of hydroxychloroquine in hospitalized patients with Covid-19. New England Journal of Medicine (2020).

26 Kaplan, E. L. \& Meier, P. Nonparametric estimation from incomplete observations. Journal of the American statistical association 53, 457-481 (1958).

27 Efron, B. Nonparametric standard errors and confidence intervals. canadian Journal of Statistics 9, 139-158 (1981).

28 Von Elm, E. et al. The Strengthening the Reporting of Observational Studies in Epidemiology (STROBE) statement: guidelines for reporting observational studies. Annals of internal medicine 147, 573-577 (2007).

\section{Acknowledgments}

The authors warmly thank the EDS APHP Covid consortium integrating the APHP Health Data Warehouse team as well as all the APHP staff and volunteers who contributed to the implementation of the EDS-Covid database and operating solutions for this database.

Collaborators EDS APHP Covid consortium: Pierre-Yves ANCEL, Alain BAUCHET, Nathanaël BEEKER, Vincent BENOIT, Mélodie BERNAUX, Ali BELLAMINE, Romain BEY, Aurélie BOURMAUD, Stéphane BREANT, Anita BURGUN, Fabrice CARRAT, Charlotte CAUCHETEUX, Julien CHAMP, Sylvie CORMONT, Christel DANIEL, Julien DUBIEL, Catherine DUCLOAS, Loic ESTEVE, Marie FRANK, Nicolas GARCELON, Alexandre GRAMFORT, Nicolas GRIFFON, Olivier GRISEL, Martin GUILBAUD, Claire HASSEN-KHODJA, François HEMERY, Martin HILKA, Anne Sophie JANNOT, Jerome 
medRxiv preprint doi: https://doi.org/10.1101/2020.07.15.20154310; this version posted July 16, 2020. The copyright holder for this preprint (which was not certified by peer review) is the author/funder, who has granted medRxiv a license to display the preprint in perpetuity.

All rights reserved. No reuse allowed without permission.

LAMBERT, Richard LAYESE, Judith LEBLANC, Léo LEBOUTER, Guillaume LEMAITRE, Damien LEPROVOST, Ivan LERNER, Kankoe LEVI SALLAH, Aurélien MAIRE, Marie-France MAMZER, Patricia MARTEL, Arthur MENSCH, Thomas MOREAU, Antoine NEURAZ, Nina ORLOVA, Nicolas PARIS, Bastien RANCE, Hélène RAVERA, Antoine ROZES, Elisa SALAMANCA, Arnaud SANDRIN, Patricia SERRE, Xavier TANNIER, Jean-Marc TRELUYER, Damien VAN GYSEL, Gaël VAROQUAUX, Jill Jen VIE, Maxime WACK, Perceval WAJSBURT, Demian WASSERMANN, Eric ZAPLETAL.

\section{Authorship}

$\mathrm{NH}$ designed the study, performed statistical analyses, and wrote the first draft of the manuscript. MSR performed statistical analyses and critically revised the manuscript. RV contributed to statistical analyses and critically revised the manuscript for scientific content. FL, NB and ASJ contributed to study design and critically revised the manuscript for scientific content. NB, ASJ, AN, NP, CD, AG, GL, MB, and AB contributed to database build process. $\mathrm{AN}, \mathrm{CB}, \mathrm{CL}, \mathrm{GA}, \mathrm{NP}, \mathrm{CD}, \mathrm{AG}, \mathrm{GL}, \mathrm{MB}$, and $\mathrm{AB}$ critically revised the manuscript for scientific content.

\section{Conflicts of interest}

Dr Hoertel has received personal fees and non-financial support from Lundbeck, outside the submitted work. Dr Lemogne reports personal fees and non-financial support from JanssenCilag, Lundbeck, Otsuka Pharmaceutical, and Boehringer Ingelheim, outside the submitted work. Dr Airagnes reports personal fees from Pfizer, Pierre Fabre and Lundbeck, outside the submitted work. Dr Limosin has received speaker and consulting fees from Janssen-Cilag outside the submitted work. Other authors declare no competing interests.

\section{Data Availability Statement}

Data from the AP-HP Health Data Warehouse can be obtained at https://eds.aphp.fr//.

\section{Disclaimer}

The views and opinions expressed in this report are those of the authors and should not be construed to represent the views of any of the sponsoring organizations, agencies, or the US government. 
medRxiv preprint doi: https://doi.org/10.1101/2020.07.15.20154310; this version posted July 16,2020 . The copyright holder for this preprint (which was not certified by peer review) is the author/funder, who has granted medRxiv a license to display the preprint in perpetuity.

All rights reserved. No reuse allowed without permission.

\section{Funding source}

This work did not receive any external funding.

\section{Role of the funding source}

\section{None}


Table 1. Characteristics of patients receiving or not receiving chlorpromazine in the matched and unmatched analytic samples.

\begin{tabular}{|c|c|c|c|c|c|c|}
\hline & $\begin{array}{c}\text { Exposed to } \\
\text { chlorpromazine } \\
\qquad \mathrm{N}=57\end{array}$ & $\begin{array}{c}\text { Not exposed to } \\
\text { chlorpromazine } \\
\qquad \mathrm{N}=12,160\end{array}$ & $\begin{array}{l}\text { Non-exposed } \\
\text { matched group } \\
\qquad \mathrm{N}=285\end{array}$ & $\begin{array}{c}\text { Exposed to } \\
\text { chlorpromazine } \\
\text { vs. } \\
\text { Not exposed to } \\
\text { chlorpromazine } \\
\text { (crude analysis) }\end{array}$ & $\begin{array}{c}\text { Exposed to } \\
\text { chlorpromazine } \\
\text { vs. } \\
\text { Not exposed to } \\
\text { chlorpromazine } \\
\text { (analysis weighted } \\
\text { by inverse- } \\
\text { probability- } \\
\text { weighting weights) }\end{array}$ & $\begin{array}{c}\text { Exposed to } \\
\text { chlorpromazine } \\
\text { vs. } \\
\text { Non-exposed } \\
\text { matched group } \\
\text { (matched } \\
\text { analytic sample } \\
\text { analysis) }\end{array}$ \\
\hline & $\mathrm{N}(\%)$ & $\mathrm{N}(\%)$ & $\mathrm{N}(\%)$ & $\begin{array}{l}\text { Chi-square test / } \\
\text { Welch's t-test (p- } \\
\text { value) }\end{array}$ & $\begin{array}{c}\text { Weighted Chi- } \\
\text { square test / } \\
\text { Weighted Welch's } \\
\text { t-test (p-value) }\end{array}$ & $\begin{array}{c}\text { Chi-square test / } \\
\text { Welch's t-test } \\
\text { (p-value) }\end{array}$ \\
\hline \multicolumn{7}{|l|}{ Characteristics } \\
\hline Sex & & & & $1.1(0.295)$ & $0.04(0.833)$ & $0.01(>0.99)$ \\
\hline Women & $24(42.1 \%)$ & $6073(49.9 \%)$ & $121(42.5 \%)$ & & & \\
\hline Men & $33(57.9 \%)$ & $6087(50.1 \%)$ & $164(57.5 \%)$ & & & \\
\hline Age (years), mean (SD) & $61.0(16.4)$ & $58.6(20.1)$ & $64.8(15.1)$ & $-1.10(0.275)$ & $-0.28(0.779)$ & $-1.64(0.105)$ \\
\hline Obesity $^{\alpha}$ & & & & $17.68(<0.001 *)$ & $3.18(0.074)$ & $<0.01(0.959)$ \\
\hline Yes & $19(33.3 \%)$ & $1628(13.4 \%)$ & $91(31.9 \%)$ & & & \\
\hline No & $38(66.7 \%)$ & $10532(86.6 \%)$ & $194(68.1 \%)$ & & & \\
\hline Smoking ${ }^{\beta}$ & & & & $4.08(0.043)$ & $0.45(0.502)$ & $0.01(>0.99)$ \\
\hline Yes & $10(17.5 \%)$ & $1092(8.98 \%)$ & 49 (17.2\%) & & & \\
\hline
\end{tabular}


No

Any medical condition ${ }^{\beta}$

Yes

No

Medication according to

compassionate use or as part of a

clinical trial

Yes

No

Any current psychiatric disorder,

including delirium ${ }^{\ddagger}$

Yes

No

Any benzodiazepine or Z-drug

Yes

No

Any antipsychotic medication other than chlorpromazine

Yes
No

Any other psychotropic medication ${ }^{\Omega}$

$\begin{array}{ll}\text { Yes } & 14(24.6 \%) \\ \text { No } & 43(75.4 \%)\end{array}$

$25(43.9 \%)$

$15(26.3 \%)$

$42(73.7 \%)$

$18(31.6 \%)$

$39(68.4 \%)$

$32(56.1 \%)$

25 (43.9\%)

$51(89.5 \%)$

$6(10.5 \%)$
11068 (91.0\%)

$32(56.1 \%)$

3477 (28.6\%)

$8683(71.4 \%)$

$3.40(0.065)$

$0.35(0.559)$

$0.01(>0.99)$

$1990(16.4 \%)$

$10170(83.6 \%)$

$75(26.3 \%)$

$210(73.7 \%)$

$66.65(<0.001 *)$

$14.93(<0.001 *)$

$0.01(>0.99)$

$678(5.58 \%)$

$11482(94.4 \%)$

$90(31.6 \%)$

$195(68.4 \%)$

1187 (9.76\%)

$10973(90.2 \%)$

$160(56.1 \%)$

$125(43.9 \%)$

$1932(15.9 \%)$

$255(89.5 \%)$

$10228(84.1 \%)$

$30(10.5 \%)$

388 (3.19\%)

11772 (96.8\%)
$220.56(<0.001 *)$

$0.01(>0.99)$

$15.90(<0.001 *)$

$0.01(>0.99)$

$130.75(<0.001 *)$

$$
3.64 \text { (0.057) }
$$

)


${ }^{\alpha}$ Defined as having a body-mass index higher than $30 \mathrm{~kg} / \mathrm{m}^{2}$ or an International Statistical Classification of Diseases and Related Health Problems (ICD-10) diagnosis code for obesity (E66.0, E66.1, E66.2, E66.8, E66.9).

${ }^{\beta}$ Assessed using ICD-10 codes for diabetes mellitus, diseases of the circulatory system, diseases of the respiratory system, neoplasms, and diseases of the blood and blood-forming organs and certain disorders involving the immune mechanism based on ICD-10 classification.

${ }^{¥}$ Assessed using ICD-10 codes (F00-F99 and R41.0).

${ }^{\Omega}$ Included any antidepressant or mood stabilizer (i.e., lithium or antiepileptic medications with mood stabilizing properties).

$* \mathrm{p}$-value is significant $(\mathrm{p}<0.05)$. 
Table 2. Associations between chlorpromazine use and the endpoint of intubation or death in the full sample and in the matched analytic sample.

\begin{tabular}{lc}
\hline Analysis & Intubation or death \\
\hline Full sample & \\
$\quad$ Number of events / Number of patients (\%) & $1,328 / 12,217(10.9 \%)$ \\
$\quad$ Chlorpromazine & $29 / 57(50.9 \%)$ \\
$\quad$ No chlorpromazine & $1,899 / 12,160(15.6 \%)$ \\
Crude analysis - hazard ratio (95\% CI; p-value) & $2.85\left(1.97-4.12 ;<0.001^{*}\right)$ \\
$\quad \begin{array}{l}\text { Multivariable analysis - hazard ratio (95\% CI; p-value) } \\
\text { Propensity score analysis with inverse probability weighting - hazard ratio } \\
\text { (95\% CI; p-value) }\end{array}$ & $1.96(1.34-2.86,<0.001 *)$ \\
Matched analytic sample & $1.67(1.09-2.56 ; 0.019 *)$ \\
$\quad$ Number of events / Number of patients $(\%)$ & $130 / 342(38.0 \%)$ \\
$\quad$ Chlorpromazine & $29 / 57(50.9 \%)$ \\
$\quad$ No chlorpromazine & $101 / 285(35.4 \%)$ \\
Crude analysis - hazard ratio (95\% CI; p-value)
\end{tabular}

* p-value is significant $(\mathrm{p}<0.05)$. 
medRxiv preprint doi: https://doi.org/10.1101/2020.07.15.20154310; this version posted July 16,2020 . The copyright holder for this preprint (which was not certified by peer review) is the author/funder, who has granted medRxiv a license to display the preprint in perpetuity.

All rights reserved. No reuse allowed without permission.

\section{Figure 1. Study cohort.}

16,170 inpatients with a positive Covid-19 RT-PCR test

12,217 adult inpatients (57 exposed to chlorpromazine and 12,160 not exposed) included in the propensity-matched and regression analyses 
medRxiv preprint doi: https://doi.org/10.1101/2020.07.15.20154310; this version posted July 16,2020 . The copyright holder for this preprint (which was not certified by peer review) is the author/funder, who has granted medRxiv a license to display the preprint in perpetuity.

All rights reserved. No reuse allowed without permission.

Figure 2. Freedom from the composite endpoint of intubation or death in the full sample $(\mathrm{N}=12,217)(\mathrm{A})$ and in the matched analytic sample $(\mathrm{N}=342)(B)$ of hospitalized patients with Covid-19 according to chlorpromazine exposure. ${ }^{¥}$
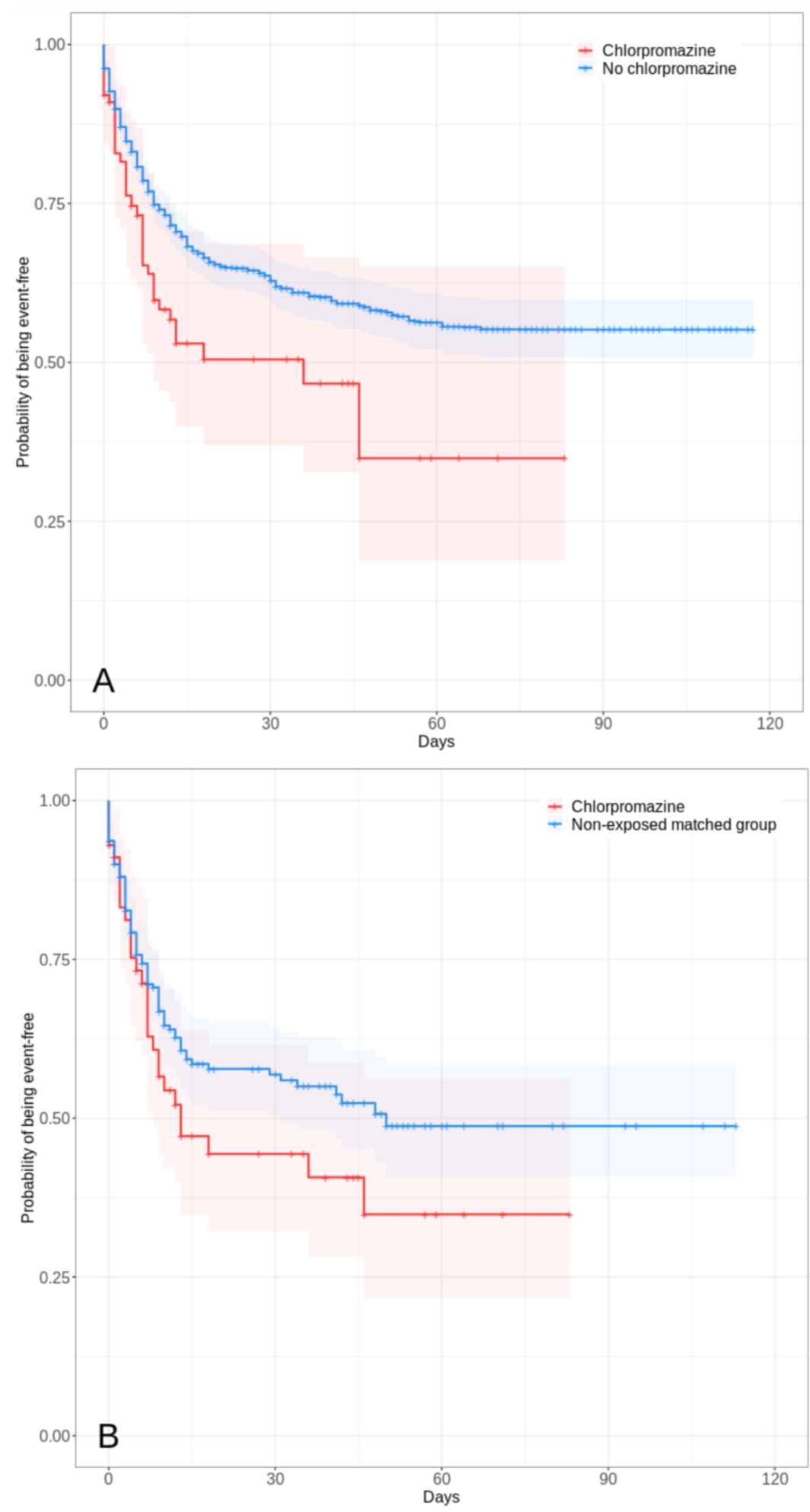

Note: The shaded areas represent pointwise $95 \%$ confidence intervals.

${ }^{¥}$ Patients were considered to be exposed to chlorpromazine if they were under this medication at admission, ascertained by an ongoing medical prescription dated of less than 3 months before hospital admission, or if they received it during the follow-up period before the end of the hospitalization or intubation or death $(\mathrm{N}=57)$. 